\title{
Public Health Risk of Cow Milk Microbial Contamination Versus Hygiene Habits Impact Analyses of Cow Milkers
}

Benjamin Makimilua Tiimub ${ }^{1,2 *}$, Paul Amihere-Ackah² ${ }^{2}$ Richard Wonnsibe Tiimob ${ }^{3}$, Enoch Gyan ${ }^{2}$, Gideon Likida Tiimob ${ }^{4}$, Judith Acheamaa Gyimah ${ }^{2}$, Elisha Tiimob ${ }^{5}$ and Baani Isaac ${ }^{2}$

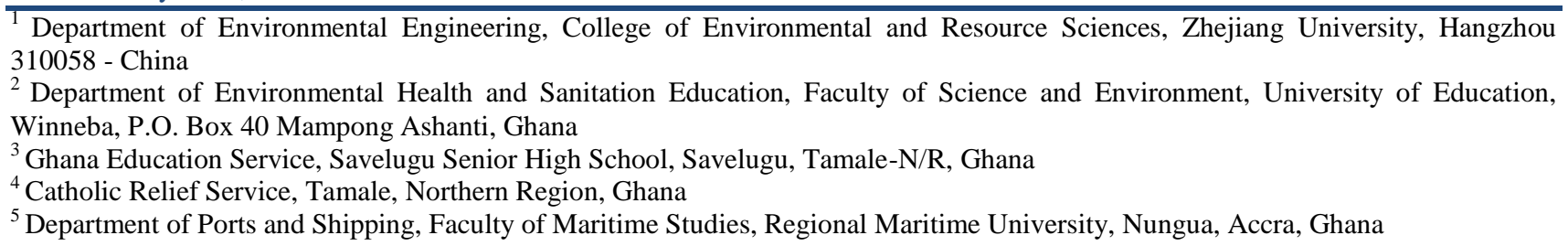

\begin{tabular}{|c|c|}
\hline $\begin{array}{c}\text { Article History } \\
\text { Received: } 30.08 .2020 \\
\text { Accepted: } 11.09 .2020 \\
\text { Published: } 30.09 .2020 \\
\\
\text { Journal homepage: } \\
\text { https://www.easpublisher.com/easjpid } \\
\end{array}$ & $\begin{array}{l}\text { Abstract: Six bacteria species, associated with raw milk contamination were } \\
\text { comparatively assessed in rural-peri urban case study using standard laboratory microscopy. } \\
\text { Entirely } 80 \text { milk samples, } ~ 500 \mathrm{ml} \text { were screened from Mampong Zongo and Daaho peri } \\
\text { urban cattle husbandry communities within the Ashanti Region of Ghana. Bacterial spots } \\
\text { discovered in the milk for relative contamination (cfu/ml) at dilution factor of } 10^{-5} \text { were: } 208 \\
\text { (12.76), } 28 \text { (12.62), } 263 \text { (5.98), } 217 \text { (14.39), } 163.5(3.65) \text { and } 34.3 \text { (3.27), respectively for } \\
\text { total bacteria count, E. coli, Staphylococcus; Bacillus; Clostridium and Salmonella species. } \\
\text { The microbial isolates were comparatively not significant (P-values > 0.05) although; } \\
\text { Bacillus spp. predominated milk at both farms. The unhygienic traits of milk handlers } \\
\text { contributed to cross contamination, predisposing consumers to high risks of bacterial } \\
\text { infections. Farmers training on hygienic habits could urgently promote higher food chain } \\
\text { safety standards. Environmental Health Departments have a major role on food hygiene } \\
\text { public education during routine nutrition action plans in these peri urban communities. Food } \\
\text { and Drugs Authority in Ghana need to perform routine quality assessment of local milk } \\
\text { products to control pathogenic infections. } \\
\text { Keywords: Cow Milk, Microbial Isolation, Contamination, Public Health. }\end{array}$ \\
\hline
\end{tabular}

Copyright @ 2020: This is an open-access article distributed under the terms of the Creative Commons Attribution license which permits unrestricted use, distribution, and reproduction in any medium for non-commercial use (Non Commercial, or CC-BY-NC) provided the original author and source are credited.

\section{INTRODUCTION}

Animal protein consumption in Ghana is below the permissible levels and the per capital consumption of milk is a rarely 31 per annum (PA) compared to the sub-Saharan Africa in average of 231PA. The average annual demand of milk in Ghana is approximately 70,000 metric tons of which more than half is being imported (FAO/GoG, 2009). Although, potential market for the local dairy production is large, its contribution to the total consumption is perceivably low under unhygienic conditions (Mhone et al., 2011). Farm characteristics and hygienic practices significantly affect milk products quality (Lan et al., 2017; Carloni et al., 2016). Consumption of raw milk lead to zoonoses because milk is often contaminated with cattle feces during milking and serves as an excellent growth medium for microorganisms (Lan et al., 2017).

Roughly, up to every third of person in developed countries is affected by food borne diseases
(FBDs) caused by consumption of hazardous substances that may contain pathogens (viruses, bacteria, parasites), chemical (heavy metals and toxins), and physical agents (glass fragments, bone chips et cetera) (WHO/FAO, 2003; Tirado and Schmidt, 2001). In Ghana, microorganisms such as Yersinia, Klebsiella, Proteus, Enterobacter, Escherichia coli, Staphylococcus, Bacillus and Mycobacterium spp. have been isolated from raw milk (Donkor et al., 2007). Escherichia coli (E. coli) has constituted indicator of fecal pollution of water and food (ISO 2013). Escherichia coli 0157:H7 is linked to consumption of a number of contaminated foods, especially undercooked ground beef and raw milk (ISO 2004), potentially causing fatal haemorrhagic enteritis or colitis characterized by bloody diarrhoea and haemolytic uraemic syndrome in humans due to the production of potent verocytoxins, associated with serious kidney damage and renal failure (Besser et al., 1993). Milk and milk products in developed and developing countries are widely contaminated with antibiotic residues 
(sulphonamides, nitrofurans, beta lactams), applied at high dosages for the treatment of diseases in dairy cattle (Sivapalasingams et al., 2004; Parekh and Subhash, 2008). Milk residue increases the number of antibiotic resistant pathogenic bacteria in persons who are not allergic to the drug whilst causing allergic reactions in sensitive persons (Oliver and Murinda, 2011).

Informal sector produced milk is scarcely regulated by state agencies in Ghana with almost 35\% marketed in two major cities (Accra and Kumasi), where its quality has been affected by pathogens and antibiotics (Aning et al., 2007). The relationship between TBC and prevalence of $S$. aureus or E. coli recently confirmed season and herd management as major influential factors in determining the quality of raw milk in northern China (Lan et al., 2016). The World Health Organization (WHO) and Food and Agriculture Organization (FAO) have pointed FBDs as contractable illnesses of an infectious or toxic nature due to the consumption of food and water, which represents the ubiquitous health issue over the past decade and is further significantly reducing economic productivity (Smith et al., 2017; Hlavsa et al., 2008). In this study, we suspected raw milk as main carrier for transmission of Tuberculosis by Mycobacterium bovis and M. tuberculosis and brucellosis by Brucella spp. and embarked upon bacteria species isolation from the raw milk samples, similar to previous analyses in the dairy food chains (Hlavsa et al., 2008; Addo et al., 2007; Al-Tahiri, 2005). This article highlights the effects of various microbial contaminants in raw cow milk in the Asante Mampong Municipality of Ghana which was determined under standard laboratory protocols. Risk factors of milk contamination at two peri urban farm gates attributed to unhygienic handling are further reported.

\section{MeTHOdOLOGY}

Study area

Asante-Mampong township is located within the Sekyere-West Municipality with a total land area of $2346 \mathrm{~km}^{2}$ and is one of the thirty (30) Administrative divisions on the northern flanks of the Ashanti region with about 88,000 people and 220 settlements (70\% rural). Mampong is the administrative capital with a population of 42,037 people. It shares boundary with Atebubu District, Sekyere East, Afigya-Sekyere, and Ejura-Sekyedumasi to the north, east, south and west respectively within longitudes $0.05^{\circ}$ and $1.30^{\circ} \mathrm{W}$ and latitudes $6.55^{\circ}$ and $7.30^{\circ} \mathrm{N}$.

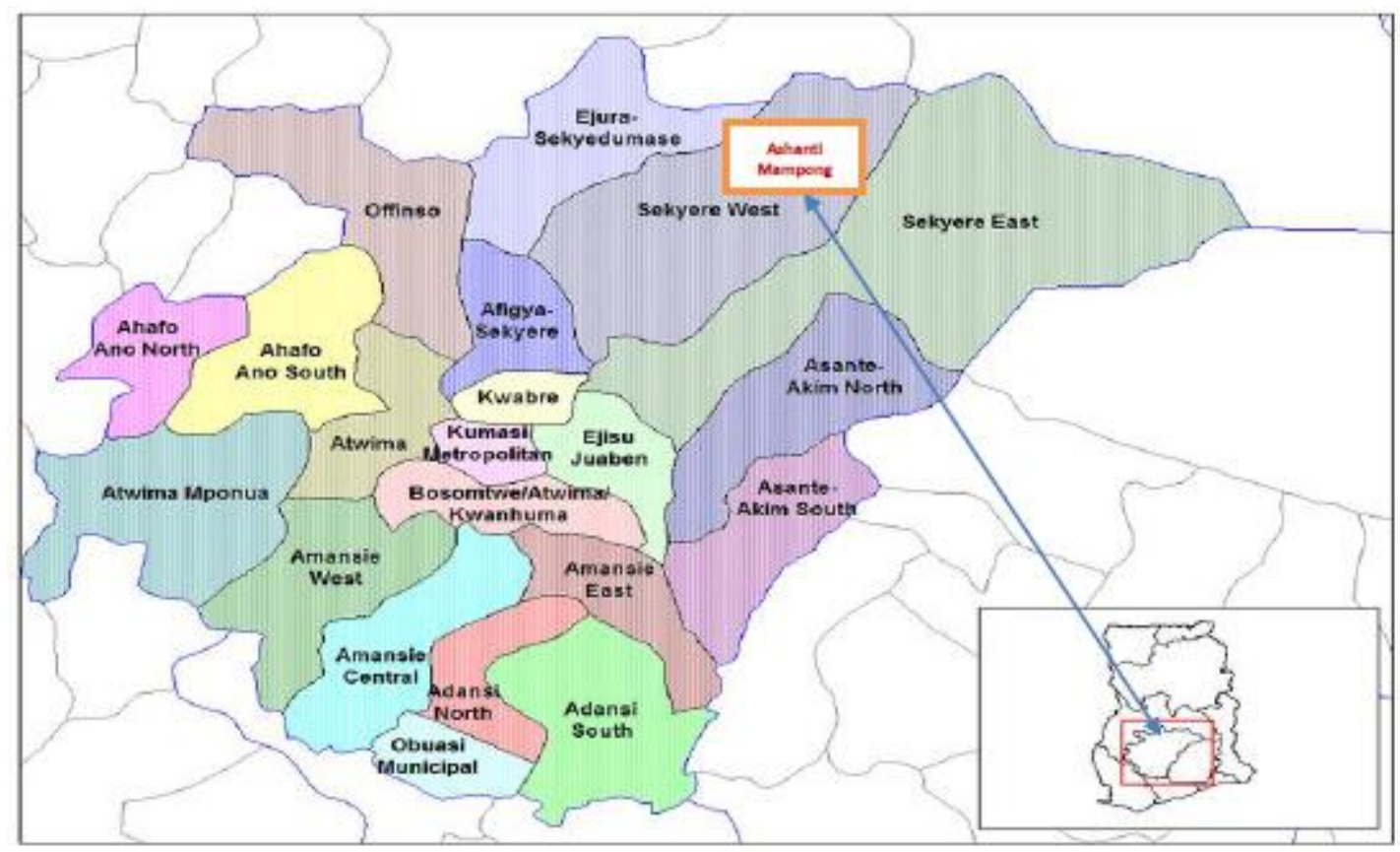

Figure 1 map of the Ashanti Region in Ghana with an arrow pointing to Ashanti Mampong Municipal where the study was conducted

\section{Study design, sampling technique and laboratory analyses}

Hygiene survey using verbal interviews were performed on small scale pastoralists under free range grazing systems. The sampling frames consisted of smallholder husbandry units with lactating cow kraals. Milking is usually done by both male and female farmers every morning from 7:00am to 8:00am and the milk is either consumed at household level, sold to the public or both. A sum of 80 (40 each from Mampong Zongo and Daaho), made up of $\sim 500 \mathrm{ml}$ of milk samples were collected using 500ML sterile bottles filled with milk that were extracted on the same day of sampling and tightly covered. The milk was stored in a cool box stocked with ice packs and transferred to the laboratory for analysis within 24 hours at the UEW-M Campus by first establishing the total bacterial counts (TBC), and 
subsequent isolation of Salmonella spp., Bacillus spp., Clostridium spp., Staphylococcus spp. and E. coli.

\section{Media preparation for serial dilutions, culturing, enumeration and detection of total viable bacteria}

All the media used in this study were prepared according to the manufacturer's instructions. Milk sample (10ML) was aseptically transferred to $99 \mathrm{ml}$ sterile Peptone Buffer Water solution (PBW) and thoroughly mixed to make $10^{-1}$ initial dilution. From the previous dilution, $1 \mathrm{ml}$ was transferred to another sterile test tube containing $9 \mathrm{ml}$ sterile peptone buffer water to make $10^{-2}$. This procedure was repeated to produce five dilutions $\left(10^{-1}-10^{-5}\right)$. The $1 \mathrm{ml}$ from each dilution was transferred into sterile Petri plates using a sterile tip followed by addition of $10-15 \mathrm{ml}$ of the desired medium. The plates were covered and swirled by gentle agitation and incubated at temperature of $37^{\circ} \mathrm{C}$. The plate count agar medium (PCA) was used for the enumeration of viable bacteria. The already prepared diluted solutions were removed from the refrigerator, kept at room temperature and labeled prior to inoculation. Two sterile PCA plates were inoculated with $0.1 \mathrm{ml}$ of the test sample from each dilution (starting with the last dilution). The sample was spread on the media surface with the aid of sterile swab and the plates were allowed to dry with their lids capped for 15 minutes. The plates were incubated at $37^{\circ} \mathrm{C}$ under aerobic condition for 48 hours to allow bacterial growth. Using a new sterile pipette for each dilution, the procedure was repeated as fore stated with further dilutions up to the first dilution and for the remaining test samples, where only consecutive critical dilution steps were chosen for the inoculation on plates. Preliminary test results showed that, critical dilution of $10^{-5}$ was the best for countable range of less than 300 colony forming units per plate (cfu/plate). Two critical dilutions for each sample of bacterial colonies on the culture plates were counted manually after the incubation period. Afterwards, plate was divided into quarters using a marker-pen and colony forming units were counted on at least two critical dilution plates by the aid of automatic colony counter. Two consecutive plate dilutions of $10^{-5}$ with less than 300 colonies were considered for record purpose (ISO 4833-1:2013). The dilutions were also used for detection and enumeration of E. coli, Salmonella spp. Bacillus spp. Clostridium spp. and Staphylococcus spp. Number of tested microbial colonies in each dilution was multiplied by the reciprocal of the dilution and recorded as cfu/ml.

\section{Detection and enumeration of salmonella spp.}

The remained initial milk sample suspensions in the conical flasks were used for isolation and presumptive identification of Salmonella spp. Buffered Peptone Water (BPW) was used as a pre-enrichment liquid medium and the initial suspensions was incubated at $37^{\circ} \mathrm{C}$ for 24 hours. About $0.1 \mathrm{ml}$ of the culture in the first stage was inoculated in a test tube containing $10 \mathrm{ml}$ of Selenite broth and incubated at $35^{\circ} \mathrm{C}$ for 48 hours. Using a sterile loop Selenite broth, the culture obtained was inoculated onto Triple Sugar Iron (TSI) and Sahol Shiga (SS) Agar and were all incubated at $37^{\circ} \mathrm{C}$ for 24 hours. Colonies of Salmonella spp. grown on TSI are yellow butts and yellow slants and a minimum positive bet of hydrogen sulphide gas $\left(\mathrm{H}_{2} \mathrm{~S}\right)$. Whitish colonies of Salmonella spp. were also picked from the SS agar media. Two consecutive plate's record dilutions of $10^{-5}$ were considered.

\section{Detection and enumeration of staphylococcus spp.}

Staphylococcus ssp. was determined using mannitol salt agar medium and inoculated using already prepared spread plated media. Two sterile spread plate agars were used and labeled prior to inoculation. One $\mathrm{ml}$ of the test sample was transferred using a sterile pipette from the last dilution to each of the two media plates. Then, a fresh sterile swab was used to spread the sample on the surface of the media. The plates were allowed to dry for about 15 minutes, inverted and incubated at $37^{\circ} \mathrm{C}$ for 48 hours. The yellow colonies in un-crowded plates were counted. Two plates containing less than 300 colonies at two successive dilutions of $10^{-}$ 5 were selected after incubation for counting and recordings using the automatic colony counter. Dilution plates $\left(10^{-1}-10^{-4}\right)$ with bacteria counts above 300 colonies were not considered for record.

\section{Detection and Enumeration of Bacillus and Clostridium spp. \\ Yeast extract media was used for the} inoculation and enumeration of Clostridium and Bacillus spp. in pasteurized plates at $80^{\circ} \mathrm{C}$ in water bath for 10 minutes to rid of all non-spore forming species of bacteria and allowed to cool for 15 minutes. The $0.1 \mathrm{ml}$ of the test sample was transferred using sterile pipette from the last dilution to each of the two media plates. Fresh sterile swab was used to spread the sample on surfaces of capped media plates and dried for 15 minutes. Thereafter, clostridium spp. was incubated anaerobically using Anaerogen system of inoculation for $48 \mathrm{hrs}$ whereas bacillus spp. was incubated aerobically for $48 \mathrm{hrs}$. Afterwards, two consecutive plates of dilution $\left(10^{-5}\right)$ were used for the counting and recording. Dilution plates $\left(10^{-1}-10^{-4}\right)$ with spots colonies above 300 were not considered.

\section{Detection and Enumeration of $E$. coli spp.}

All test samples suspected as $E$. coli colonies during detection of Salmonella were removed from the refrigerator, thawed at room temperature and used for detection of E. coli. Petri dishes with MacConkey agar media were labeled and divided into two equal halves. A sterile loop was dipped into a thawed milk sample and streaked onto MacConkey agar plates at differential media for identification of $E$. coli. Plates were inverted and incubated at $37^{\circ} \mathrm{C}$ for 48 hours. E. coli grown on MacConkey agar were dry, medium in size, pink in color and appeared singular or in groups. After 48 hours of incubation, two consecutive plates of dilution $10^{-5}$ 
were used for counting and recording. The dilution plates $\left(10^{-1}-10^{-4}\right)$ above 300 colonies were not considered.

\section{Chi- square test on the ranked impact factors of} hygienic habits

Observed impact factors of the hygienic habits of cow milk workers on farms were analyzed by Chi-Square test, using the formula below:

$$
\begin{array}{r}
\chi^{2}=\sum_{i=1}^{n} \frac{\left(O_{i}-E_{i}\right)^{2}}{E_{i}} \\
(\text { or }), \\
\chi^{2}=\sum \frac{(\text { OHHF }-E H H F)^{2}}{E H H F}
\end{array}
$$

Where; observed hygiene habit frequency $\left(O_{i}\right.$ or $O H H F)=$ distribution of variables (effects) in the milk sample.
Expected hygiene habit frequency $\left(E_{i}\right.$ or $\left.E H H F\right)=$ Total rows frequencies $\mathrm{x}$ Total columns frequencies Total number of observations

\section{Data analysis}

Data obtained from the experiment were keyed into Origin 8 worksheet for statistical analysis using Gen Stat procedure Library Release, P119.1. Standard averages (means) of the microbial data were separated by the least significant difference (LSD) test at $\mathrm{P} \leq 0.05$ level of significance.

\section{RESUlTS}

\section{Hygiene practices of farmers and risk of microbial contamination of raw cow milk}

The survey data proofed highly insignificant correlations between the levels of bacterial contamination at both Dado and Mampong Zongo sites for the corresponding Chi-values.

\begin{tabular}{|c|c|c|c|c|c|c|c|c|c|c|}
\hline \multirow[t]{2}{*}{$\begin{array}{l}\text { Milk study } \\
\text { site }\end{array}$} & \multirow{2}{*}{$\begin{array}{l}\text { Ranked factor } \\
\text { interpretation of } \\
\text { clustered } \\
\text { descriptive } \\
\text { hygiene habit } \\
\text { serial number of } \\
\text { descriptive } \\
\text { hygiene habit }\end{array}$} & \multicolumn{3}{|c|}{$\begin{array}{l}\text { Ranked health statistic } \\
\text { on number of observed } \\
\text { hygienic practices with } \\
\text { suspected severe } \\
\text { adverse effect and their } \\
\text { corresponding chi- } \\
\text { values (SSAE) }\end{array}$} & \multicolumn{3}{|c|}{$\begin{array}{l}\text { Ranked health statistic } \\
\text { on number of observed } \\
\text { hygiene practices with } \\
\text { suspected mild adverse } \\
\text { effect with } \\
\text { corresponding chi- } \\
\text { values (SMAE) }\end{array}$} & \multicolumn{3}{|c|}{$\begin{array}{l}\text { Ranked health statistic } \\
\text { on number of observed } \\
\text { hygiene practices with } \\
\text { zero (negligibly } \\
\text { expected) impact factor } \\
\text { with their } \\
\text { corresponding chi- } \\
\text { values (PZHIF) }\end{array}$} \\
\hline & & $\mathrm{F}$ & $\begin{array}{l}\%= \\
(\mathrm{f} / \mathrm{n})\end{array}$ & $\chi_{\text {value }}^{2}$ & $\mathrm{~F}$ & $\begin{array}{l}\%= \\
(\mathrm{f} / \mathrm{n})\end{array}$ & $\chi_{\text {value }}^{2}$ & $\mathrm{~F}$ & $\begin{array}{l}\%= \\
(\mathrm{f} / \mathrm{n})\end{array}$ & $\chi^{2}$ value \\
\hline Daaho cattle & 1 & 38 & $95^{\mathrm{VP}}$ & 285.242 & 1 & $2.5^{\mathrm{IP}}$ & 0.3141 & 1 & $2.5^{\mathrm{IP}}$ & 0.3141 \\
\hline Farm milk & 2 & 37 & $93^{\mathrm{P}}$ & 279.595 & 3 & $7.5^{\mathrm{G}}$ & 0.9424 & 0 & 0 & Nil \\
\hline samples & 3 & 35 & $88^{\mathrm{P}}$ & 264.582 & 5 & $12^{\mathrm{G}}$ & 1.5706 & 0 & 0 & Nil \\
\hline$(\mathrm{n}=40)$ & 4 & 38 & $95^{\mathrm{VP}}$ & 285.240 & 2 & $5^{\mathrm{IP}}$ & 0.2157 & 0 & 0 & Nil \\
\hline & 5 & 39 & $98^{\mathrm{VP}}$ & 294.607 & 1 & $2.5^{\mathrm{IP}}$ & 0.3141 & 0 & & Nil \\
\hline Mampong & 1 & 39 & $98^{\mathrm{VP}}$ & 294.607 & 1 & $2.5^{\mathrm{IP}}$ & 0.3141 & 0 & 0 & Nil \\
\hline Zongo cattle & 2 & 37 & $93^{\mathrm{P}}$ & 379.595 & 3 & $7.5^{\mathrm{G}}$ & 0.9424 & 0 & 0 & Nil \\
\hline farm milk & 3 & 36 & $90^{\mathrm{P}}$ & 270.229 & 4 & $10^{\mathrm{G}}$ & 1.2565 & 0 & 0 & Nil \\
\hline samples & 4 & 39 & $98^{\mathrm{VP}}$ & 294.607 & 1 & $2.5^{\mathrm{IP}}$ & 0.3141 & 0 & 0 & Nil \\
\hline$(n=40)$ & 5 & 38 & $95^{\mathrm{VP}}$ & 285.242 & 2 & $5^{\mathrm{IP}}$ & 0.2174 & 0 & 0 & Nil \\
\hline Total & 10 & 376 & & & 23 & & & 1 & & \\
\hline
\end{tabular}

Table 1. Ranked health impact projections from observed effects of hygiene practices of milk farmers from Daaho and Zongo with risk of raw milk cross contamination.

$(\mathrm{N}=80)$

Interpreted $\quad[$ very poor $=$ VP $($ severe effect $=95 \%$ and above score $)$; poor $=\mathrm{P}$ (mild adverse effect between 50 observed $\quad 94 \%$ score); good = G (between 6-49\% score); improved practice = IP (score of 5\% and below) rank Impact

factor

Key: $\mathrm{N}=$ total sample size; $\mathrm{n}=$ sample size; $\mathrm{F}=$ frequency; SSAE = Suspected severe adverse effect; SMAE = Suspected mild adverse effect; PZHIF = Presumably zero/negligible health impact factor.

It depicted severe adverse effects of milk farmers' poor hygienic habits ranking maximally between $\left(X^{2} \leq 264.582\right.$ and $\left.X^{2} \geq 294.607\right)$ within 90 $95 \% \mathrm{CI}$ on the estimated impact scale; and minimally between $\left(X^{2} \leq 0.216\right.$ and $\left.X^{2} \geq 1.571\right)$ for the suspected mild adverse effects in levels 1-5 on the impact scale. The results hardly trended in favor of negligible health impact of farmer's hygienic practices influencing milk 
contamination. It typified $\left(\mathrm{X}^{2} \sim \mathrm{Nil}\right)$ with respect to zero or unidentifiable risk declaration. A few among the observed cases were counted as improved practices $(2.5$ - 5\% levels on the descriptive hygiene impact scale 1-5 effects). Good practices, often observed from both farms ranked between $7.5 \%-12.5 \%$ on the descriptive hygiene impact scale 1 - 5 effects (Table 1).

\section{Descriptive hygiene habits of milking cattle farmers (i-v) effects shown on Table 1. \\ i. Hygiene education of cow milk farmers}

All the encountered cattle farmers $(\mathrm{N}=80)$ involved in milk extraction lacked formal class room and informal or frequent extension education. Their levels of consciousness to occupational hygiene issues were apparently abysmal. Their disclosed sources of knowledge were typically from natural acquaintances and daily interactions with the cattle within kraals and off-kraal grazing rangelands.

Synergistic impact factor attribute selected for the poor educational status (effect score number 1) of the milking farmers which reflected their poor hygienic habits and accounted for the deterioration of milk quality at farm gates was marked by suspected severe effects (SSAE) on Table 1.

\section{ii. Dress codes of cow milk farmers}

Five main poor dressing codes were encountered throughout the on-farm observational studies: (i) short sleeved shirt; (ii) short pair of mini trouser worn with lower limbs and legs exposed; (iii) exude of body sweat soaked in dresses, stuck on exposed arms hands, face and other body parts; (iv) no face mask was worn during whilst milking cows; (v) no hand gloves were worn while manipulating teats of cows' udder during milk extraction and (vi) no artificial milk extractor was used for milking. The deterministic synergistic impact factor attributes for effect 2 scores (i, ii, iv, v and vi) were mainly considered SSAE and occasionally SAME for (ii and iii) (Table 1).

\section{iii. Daily hand washing practices of cow milk farmers}

The cow farmers usually visit toilets early mornings and often wash their hands with soap and clean water before extracting cow milk. This habit was rated one of the suspected unhygienic negative attitudes influencing milk cross contamination. Assessment of the frequency of the hand washing with antiseptics revealed was practiced intermittently, when they remembered to do so and had some soap or water around. These subjects were never intuited to wash their hands properly on the basis of health compliance. The long-term synergistic impact factor attributes selected for effect 3 scores were SSAE and SMAE (Table 1).

\section{iv. The cleaning of animal udder prior to milking}

General practice was an observed act of using small quantum of first batch of the milk drawn between the palms of the cattle boys to wash the foreskin of udders before actual milking on daily basis. Given that early milk was subsequently used to rinse the hands of the cowboys, which from their perceptions, contains the glut of natural antibiotics for initiation of selfpacification or purification, enzyme catalysis for more milk to flow and detoxification of germs. Even though, they had no scientific bases to justify their claims, they applied the indigenous technique vividly. This habit was strongly suspected as one of the main causes of large scale bacterial cross contamination of raw cow milk through zoonotic mechanism of human-animalmicrobial-transfer-agents and could be explored by conducting tracer studies to pool more evidence. Hence, the synergistic impact factor attributes selected for effect score number 4 were mainly SSAE and occasionally SMAE (table 1).

\section{v. Collection and storage mediums for milk}

The cow milkers mainly collected milk using plastic bowls, rinsed with first batch of daily collection and occasionally river or rain water of questionable quality standard. The containers were placed between their legs or directly on the contaminated ground. That required pulling the animals' hind legs for better access to the cow's udder and teats for milking from juxtapositions. The usage of uncovered devices for milk storage further attracted house flies to settle on the containers. The cattle boys often spent some time chasing these flies using pieces of leafy twigs or old dirty rags. These poor hygienic practices exposed the raw milk to drops of air and soil borne pathogens through open sides of the collection/storage containers leading to gross cross contamination. The synergistic impact factor attributes selected for this number 5 effect score were mainly SSAE and occasionally SMAE (table $1)$.

\section{Microbial quality aspects of milk}

Contamination levels of the six bacteria microbes (total bacteria, E. coli, Staphylococcus; Bacillus; Clostridium and Salmonella species) assessed from 80 milk samples are presented with their covariance and standard errors (Figure 2 and Table 2) respectively. Averagely, Staphylococcus spp. $(246.7 \mathrm{cfu} / \mathrm{ml})$ dominated, whilst Salmonella spp. $(31 \mathrm{cfu} / \mathrm{ml})$ was the least in the entire milk samples screened (Figure 2). 
Table 2. Covariance and Standard Error margins within microbiological quality parameters of raw cow milk from Mampong-Zongo and Daaho.

\begin{tabular}{lllllll}
\hline Treatment & $\begin{array}{l}\text { Total Viable } \\
\text { Bacteria Load } \\
(\mathbf{T B L})(\mathbf{c f u} / \mathbf{m l})\end{array}$ & $\begin{array}{l}\text { Bacillus } \\
\boldsymbol{s p p} \\
(\mathbf{c f u} / \mathbf{m})\end{array}$ & $\begin{array}{l}\text { Clostridium } \\
\boldsymbol{s p p}(\mathbf{c f u} / \mathbf{m l})\end{array}$ & $\begin{array}{l}\text { E. coli } \\
(\mathbf{c f u} /)\end{array}$ & $\begin{array}{l}\text { Salmonella } \\
(\mathbf{c f u} / \mathbf{m l})\end{array}$ & $\begin{array}{l}\text { Staphylococcus } \\
\boldsymbol{s p p}(\mathbf{c f u} / \mathbf{m l})\end{array}$ \\
\hline Zongo & 227 & 245 & 164 & 0.00 & 38.7 & 246.7 \\
Daaho & 188 & 189 & 163 & 56 & 31.0 & 226.0 \\
Mean & 208 & 217 & 163.5 & 28 & 34 & 236.3 \\
LSD $(0.05)$ & $\mathrm{NS}$ & 54.657 & $\mathrm{NS}$ & 14.90 & $\mathrm{NS}$ & $\mathrm{NS}$ \\
C.V\% & 12.9 & 7.2 & 6.9 & 15.2 & 27.8 & 5.5 \\
SE & 12.76 & 14.39 & 3.65 & 3.65 & 3.27 & 5.98
\end{tabular}

$\mathrm{SE}=$ Standard Error, LSD = Least Significant Difference, C.V\% = Co-efficient of variation NS = Not significant.

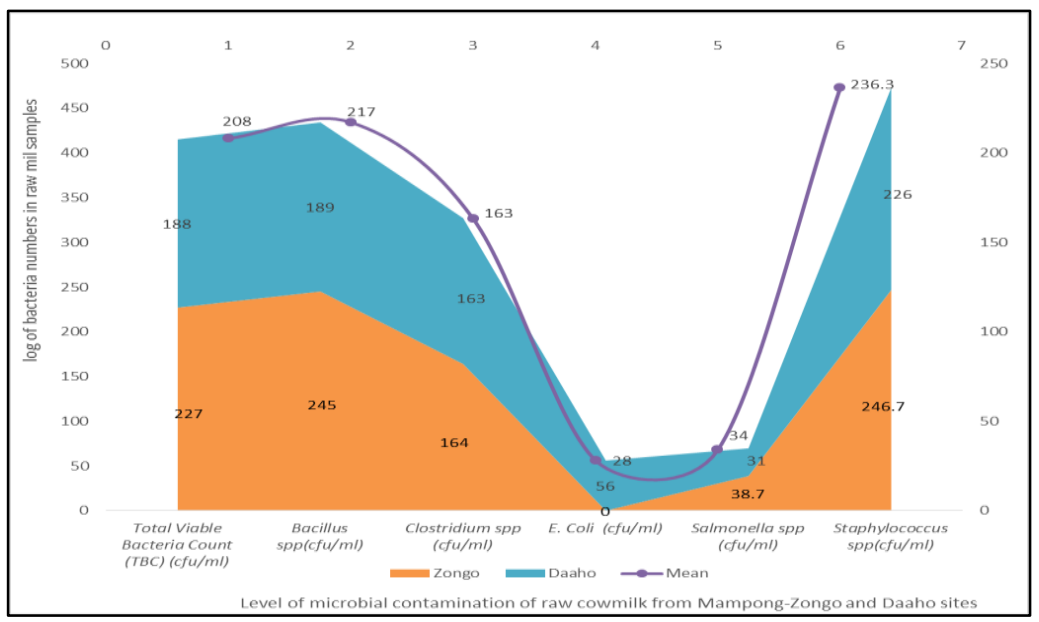

Figure 2: microbiological quality of raw cowmilk from the Mampong Zongo and Daaho study sites.

\section{DISCUSSION}

Total bacteria contamination status of milk

Generally, there was no significant difference in total bacteria load (TBL) $(\mathrm{P} \geq 0.217)$, between Mampong and Daaho milk collection stations, even though, Mampong Zongo recorded higher numbers (227 cfu/ml) than Dahoo (188 cfu/ml) with an overall average $(208 \mathrm{cfu} / \mathrm{ml})$ and standard error margin $(12.76$ $\mathrm{cfu} / \mathrm{ml}$ ) (Figure 2; Table 2). These findings corroborate with previous raw milk quality data of Addo et al. (2001); Donkor et al., (2007); Pandey and Voskuil (2011) and Tahiri et al., (2006) in Ghana, Zambia; and Jordan respectively where higher bacterial numbers in tested raw milk were earlier reported. Adesiyun, et al (1995) earlier found milk drawn from healthy animals contained < $1000 \mathrm{cfu} / \mathrm{mL}$ TBL. High temperatures could enhance proliferation of bacterial in raw milk (Addo et al., 2001). Ambient temperatures coupled with lack of cooling facilities mediate total bacterial replication (Hempen et al., 2004). Correlation between
TBC, S. aureus and E. coli was significant in our studies and confirming the reports in Northern China where seasonal temperatures and poor herd management practices affected TBC in raw milk (Lan et al., 2016; Mhone et al., 2011). Cross-contamination due to poor hygienic habits of handlers coupled with invasion by houseflies significantly reduce milk quality (Carloni et al., 2016).

\section{E. coli in milk}

Significantly higher level of E. coli at Daaho than Mampong Zongo $(\mathrm{P} \leq 0.004)$ justified the extent of contamination of the raw milk. Mampong Zongo recorded $245 \mathrm{cfu} / \mathrm{ml}$ compared to $189 \mathrm{cfu} / \mathrm{ml}$ at Dahoo with an average and standard error margin of 217 $\mathrm{cfu} / \mathrm{ml}$ and $14.39 \mathrm{cfu} / \mathrm{ml}$ respectively. Least significant E. coli difference between both farms was $54.657 \mathrm{cfu} / \mathrm{ml}$ (table 1; Figure 2). Enterobacteriaceae family of $E$. coli, in a particular coliform suggests faecal contamination due to poor food hygiene practices (Mhone et al., 2011). The findings corroborate with 
outcomes of similar studies in Ghana that identified small percent $(2.1 \%)$ of $E$. coli in raw milk (Donkor et al., 2007). Elsewhere in Tanzania, about $4.1 \%$ to $6.3 \%$ has been reported by Kivaria et al., (2006b); Karimuribo et al., (2005) and Kivaria et al., (2006a). Several E. coli strains are noted of higher pathogenesis risk of milk among consumers. Enterohaemorrhagic type of E. coli $\mathrm{O} 157: \mathrm{H7}$ and verocytotoxigenic are behind haemorrhagic colitis infections whilst $E$. coli O157: H7 causes deadly diarrhoea in humans (John et al., 2001).

\section{Staphylococcus bacteria in milk}

Staphylococcus spp. from both farms was not significantly different $(\mathrm{P} \geq 0.193)$ in milk. The overall average from both farms was $236.3 \mathrm{cfu} / \mathrm{ml}$, but, Zongo recorded highest numbers $(246.7 \mathrm{cfu} / \mathrm{ml})$ as compared to Daaho (226.0 cfu/ml) (Figure 2 and Table 2). Staphylococcus aureus in milk is attributable to mastitis infection among the lactating cows, mostly manifested in the mucous membrane and skin of most warmblooded animals including human beings (Richard, 1998). High count of Staphylococcus aureus in both farms might be due to humans since up to $60 \%$ are nasal carriers and $5-20 \%$ of people harbour the organism as part of their normal skin flora (FAO 2008). Consumption of $S$. aureus contaminated milk constitutes health hazard since about $10 \%$ of mastitis Staphylococci are biomarkers of heat stable enterotoxins (Richard, 1998). Some S. aureus report in Zimbabwe was linked to gastroenteritis and enterotoxins (Mhone et al., 2011).

\section{Salmonella bacteria in milk}

Salmonella spp. in milk at both study sites was not significantly different ( $\mathrm{P} \geq 0.483$ ); approximately (34.0 cfu/ml overall average), and the milk from Zongo was more contaminated $(38.7 \mathrm{cfu} / \mathrm{ml})$ than Daaho $(31 \mathrm{cfu} / \mathrm{ml})$ (figure 1 and table). Invasions of raw milk by Salmonella bacteria strains were reported from similar Ghanaian sites and elsewhere in Ethiopia (Donkor et al., 2007; Dehinenet et al., 2013). Poor animal housing and hygiene practices cause milk products poisoning by Salmonella spp. (Donkor et al., 2007).

\section{Clostridium spp. in milk}

Spore forming Clostridia in milk from both farms were not significantly different $(\mathrm{P} \geq 0.924)$, but, relatively higher numbers $(164 \mathrm{cfu} / \mathrm{ml})$ at Mampong and $(163 \mathrm{cfu} / \mathrm{ml})$ at Daaho suggested poor hygienic states of kraal workers leading to cross contamination by clostridia spores from feed, faeces and soil at the cow milking sites (Figure 2; Table 2). Faeces contaminate cow teats and so, cleaning teats prior to milking may merely reduce any attached dirt and spores to some extent in raw milk, but not preventing total microbial contamination (Lan et al., 2016; Vissers et al., 2007).

\section{Bacillus spp. in milk}

Bacillus spp. numbers in contaminated milk from Mampong $(245 \mathrm{cfu} / \mathrm{ml})$ was higher than the Daaho $(189 \mathrm{cfu} / \mathrm{ml})$ with significant difference $(\mathrm{P} \leq 0.048)$ between them (table 1 ). The $B$. cereus is a common soil inhabitant frequently isolated from raw cow milk (Lan et al., 2016), and often contain spores transferred from feed and faeces (Vissers et al., 2007). To safeguard the health of consumers, more education about pretreatment by boiling against $B$. cereus should be given to milk producers, handlers and consumers (Agenbag, 2007; Al-Tahiri, 2005). Our findings highlight the need to apply recommended food safety practices, critically following the systemic Hazard Analysis Critical Control Point (HACCP) requirements. This preventative system emphasizes more control than end-product testing, because the effectiveness of microbiological examination in assessing the milk safety is limiting (Vivekanand, 2015; Dehinenet et al., 2013).

\section{CONCLUSION}

The findings elucidated that milk produced in these peri urban settings is improperly regulated by any government or private agency during routine checks. It was discovered that short falls in hygienic practices (lack of cleaning of animal house floors, poorly washing hands and udder before milking, milking sick animals and those with udder problems, use of contaminated water for cleaning hands, unhygienic storage containers and exposure of stored milk after milking under ambient temperature leading to microbial growths) within farm gates apparently affected or reduced the quality. Milk samples contained higher total bacterial loads than required international safety standards, indicating that these sources were poor in terms of microbiological quality because milk should not exhibit more than $5 \times 10^{5}$ bacteria conjugates per milliliter for acceptability and consumption. The infectious pathogens discovered potentially cast threats of zoonotic outbreaks such as bovine tuberculosis, brucellosis, anthrax, listeriosis, salmonellosis and leptospirosis. Hence, the milk produced by small-scale livestock keepers in the Asante Mampong jurisdiction was generally below acceptable standards for human consumption without further processing. Consumption of raw milk/products such as Wagashi and Burchina posed further health risks to public consumers in this study, suggesting that hygiene standards of milk value chains must be monitored and keenly regulated in various processing, packaging, handling and distribution processes to serve the public who patronize it. Milk pasteurization, proper hand washing before milking and cleaning of storage containers should be applied at farm gates before distribution to consumers to reduce complicated risks of milk-borne infections.

\section{Recommendation}

It is suggested solidly that stakeholders mandatorily contribute in routine quality assessment of milk produced by small-scale livestock keepers for 
public consumption whilst educating them about the dangers milk contaminated diseases. The closest Environmental Health and Agricultural Science Education Departments of the University of Education, Winneba to where Mampong and Daaho communities are located should liaise with other public institutions to strictly adopt/enforce hygienic measures towards proper food handling practices to forestall the safety of locally produced milk.

\section{Declaration}

Authors jointly declare that no conflict of interest exist among them for this original article.

\section{Acknowledgement}

The Government of Ghana (National Commission on Tertiary Education) is highly appreciated for approval and payment of the 2016 Annual Book and Research Allowance to Lecturers in Public Universities at the University of Education, Winneba, Ashanti Mampong Campus to undertake this case study.

\section{Highlights \\ - Farmers' unhygienic habits cross contaminated milk with microbes. \\ - E. coli, Staphylococcus, Bacillus, Clostridium and Salmonella contamination numbered as high-risk factors to the health of public consumers of dairy food products. \\ - Bacillus spp. predominated the contaminated milk samples at the farm gates. \\ - Training milk-processing experts or educating famers to improve upon their hygienic habits is sine qua non to promoting acceptable food safety standards in rural-peri urban communities.}

\section{REFERENCES}

1. Addo, K.K., Mensah, G.I., Aning, K.G., Nartey, N., Nipah, G.K., Bonsu, C., Akyeh, M.L., \& Smits, H.L. (2007) Microbiological quality and antibiotic residues in informally marketed raw cow milk within the coastal savannah zone of Ghana. Journal of Tropical Medicine and International Health 16(2), $227-232$.

2. Adesiyun, A.A., Webb, L., \& Rahman, S. (1995) Microbiological quality of raw cow milk at collection centers in Trinidad, Journal of Food Prod., 58: 448.

3. Agenbag, M. (2007). The management and control of milk hygiene in the informal sector by environmental health services in South Africa. DOI -10.13140/RG.2.1.1145.896.

4. Al-Tahiri, R. (2005). A comparison on microbial conditions between traditional dairy products sold in Karak and same products produced by modern dairies. Pakistan Journal of Nutrition 4(5), 345 348.
5. Aning, K.G., Donkor, E.S., Omore, A., Nurah, G.K., Osafo, E.L.K., \& Staal, S. (2007). Risk of Exposure to Marketed Milk with Antimicrobial Drug Residues in Ghana.

6. Besser, R. E., Lett, S. M., Weber, J. T., Doyle, M. P., Barrett, T. J., Wells, J. G., \& Griffin, P. M. (1993). An outbreak of diarrhea and hemolytic uremic syndrome from Escherichia coli O157: H7 in fresh-pressed apple cider. Jama, 269(17), 22172220.

7. Carloni, E., Petruzzelli, A., Amagliani, G., Brandi, G., Caverni, F., Mangili, P., \& Tonucci, F. (2016). Effect of farm characteristics and practices on hygienic quality of bovine raw milk used for artisan cheese production in central Italy. Anim Sci J. 2016 Apr; 87(4):591-9. doi: 10.1111/asj.12452.

8. Dehinenet, G., Mekonnen, H., Ashenafi, M., \& Emmanuelle, G. (2013). Determinants of raw milk quality under a small holder production system in selected areas of Amhara and Oromia National Regional States, Ethiopia. Agriculture and biology journal of North America, USA.

9. Donkor, E.S., Aning, K.G., \& Quaye, J. (2007). Bacterial contaminations of informally marketed raw milk in Ghana. Ghana Medical Journal 41(2), $58-61$.

10. Food and Agriculture Organization (FAO)/Government of Ghana (GoG) (2009). The State of Food and Agriculture 2009: Livestock in the Balance. Rome 2009.

11. Food and Agriculture Organization of the United Nations (FAO); Climate Change: Implications for Food Safety. (2008). Rome: Food and Agriculture Organization of the United Nations, 2008. (Accessed April 15, 2009) http://www.fao.org/docrep/010/i0195e/i0195e00.ht $\underline{\mathrm{m}}$.

12. GenStat Release 11.1 (PC/Windows) 28 April 2016 18:27:29. Copyright 2008, VSN International Ltd. Registered to: TEAM TBE 2008-06-19.

13. Hlavsa, M.C., Moonan, P.K., Cowan, L.S., Navin, T.R., Kammerer, J.S., Morlock, G.P., Crawford, J.T., \& Lobue, P.A. (2008) Human tuberculosis due to Mycobacterium bovis in the United States, 1995 2005. Clin Infect Dis. 15, 47(2):168-75. doi: 10.1086/589240.

14. International Standard Organization (ISO) (2004). Microbiology of food and animal feeding stuffs Horizontal method for the detection and enumeration of Enterobacteriaceae. International Organization for Standardization (ISO 215282:2004). pp. 1 - 12 .

15. ISO. (2013). Microbiology of the food chain Horizontal method for the enumeration of microorganisms. International Organization for Standardization (ISO 4833-1:2013). pp. 1 - 10.

16. John, E.C., Yvonne, J., Nicholas, J.S., \& Mary, F.H. (2001). A survey of the prevalence of Escherichia coli O157 in raw meats, raw cow's milk and raw-milk cheeses in south-east Scotland. 
International Journal of Food Microbiology 66: 63 $-69$.

17. Lan, X.Y., Zhao, S.G., Zheng, N., Li, S.L., Zhang, Y.D., Liu, H.M., McKillip, J., \& Wang, J.Q. (2017) Short communication: Microbiological quality of raw cow milk and its association with herd management practices in Northern China. $J$ Dairy Sci. 100(6), 4294-4299. doi: 10.3168/jds.2016-11631.

18. Mhone, T.A., Matope, G., \& Saidi, P.T. (2011). Aerobic bacterial, coliform, Escherichia coli and Staphylococcus aureus counts of raw and processed milk from selected smallholder dairy farms of Zimbabwe. Int J Food Microbiol. 151(2), 223-8. doi: 10.1016/j.ijfoodmicro.2011.08.028.

19. Nicholson, C.F., Mwangi, L., Staal, S.J., \& Thornton, P.K. (2003). Dairy Cow Ownership and Child Nutritional Status in Kenya. Selected paper presented at the 2003 AAEA Annual Meetings, Montréal, Québec, Canada, 2003.

20. Oliver, S.P., \& Murinda, S.E. (2011). Milk and raw milk consumption as a vector for human disease. (Edited by D.O. Krause and S. Hendrick). CAB International. Zoonotic Pathogens in the Food Chain.231 pp.

21. Pandey, G.S., \& Voskuil, G.C.S. (2011). Manual on Milk safety, quality and hygiene. Golden Valley agricultural Research Trust, Zambia. 52pp.

22. Parekh, T.S., \& Subhash, R. (2008). Molecular and bacteriological examination of milk from different milk animals with special reference to Coliforms. Current Research in Bacteriology 1(2), 56 - 63.

23. Richard, L.W. (1998) Living with Staphylococcus aureus. Illinois Livestock Trail. University of Illinois - College of ACES Department of Animal Sciences - University of Illinois Extension.

24. Schoder, D., Maichin, A., Lema, B., \& Laffa, J. (2013) Microbiological quality of milk in
Tanzania: from Maasai stable to African consumer table. Journal of Food Protection 76(11):1908 1915.

25. Sivapalasingams, S., Friedman, C.R., Cohen, L., \& Tauxe, R.V. (2004) Fresh produce: a growing cause of outbreaks of foodborne illness in the United States. Journal of Food Protection 67(10), $2342-235$.

26. Smith, K.C., Inns, T., Decraene, V., Fox, A., Allen, D.J., \& Shah, A. (2017). An outbreak of norovirus GI-6 infection following a wedding in North West England. Epidemiol Infect. 145(6),1239-1245. doi: 10.1017/S0950268816003368. Epub 2017 Jan 30.

27. Tahiri, I., Makhlouf, J., Paquin, P., \& Fliss, I. (2006). Inactivation of food spoilage bacteria and Escherichia coli O157:H7 in phosphate buffer and orange juice using dynamic high pressure. Food Research International 39, pp. 98-105.

28. Tirado, C., \& Schmidt, K. (2001) WHO surveillance programme for control of food-borne infections and intoxications: preliminary results and trends across greater Europe. J Infect. 43 (1), 80-84.

29. Vissers, M.M., Te-Giffel, M.C., Driehuis, F., DeJong, P., \& Lankveld, J.M. (2007) Minimizing the level of Bacillus cereus spores in farm tank milk. $J$ Dairy Sci. 90(7), 3286-3293.

30. Vivekanand, N. (2015). Importance of milk safety and hygiene practices in quality trend. June 1, 2015 LinkedIn. http://www.linkedin.com/in/vivekanand-nalla4b1a9728/detail/recent-activity/posts.

31. World Health Organization (WHO)/FAO. (2003). Diet, nutrition, and the prevention of chronic disease. TRS 916. Geneva, World Health Organization. 